\title{
Fiscal convergence in the European Union
}

\section{Evžen Kočenda a,b,c, Ali M. Kutan ${ }^{\text {b,d,e, }}$, Taner M. Yigit ${ }^{\mathrm{f}, *}$}

a CERGE-EI, Charles University and the Academy of Sciences, Prague, Czech Republic

b The William Davidson Institute (WDI), MI, United States

c CEPR, London, United Kingdom

d Southern Illinois University Edwardsville, United States

e The Emerging Markets Group, London, United Kingdom

${ }^{\mathrm{f}}$ Bilkent University, Ankara, Turkey

\section{A R T I C L E I N F O}

\section{Article history:}

Received 27 February 2008

Received in revised form 28 May 2008

Accepted 23 June 2008

Available online 25 July 2008

\section{JEL classification: \\ $\mathrm{C} 23$ \\ E42 \\ E61 \\ F02 \\ $\mathrm{H} 60$ \\ P50 \\ Keywords: \\ Convergence \\ European Union \\ Integration \\ Fiscal discipline \\ Transition \\ Eurozone}

\begin{abstract}
A B S T R A C T
We empirically examine the fiscal convergence of the recent ten European Union (EU) members using the Maastricht fiscal convergence criteria. We test for absolute beta and sigma convergence of the new members in comparison to the Maastricht benchmarks, as well as the EU15 figures, using methodologies that allow for structural breaks. The results show poor fiscal performance in the European Union in general, suggesting that monetary unions do not necessarily encourage fiscal convergence for its members.
\end{abstract}

(c) 2008 Elsevier Inc. All rights reserved.

\section{Introduction, motivation, and our approach}

In this paper, we study fiscal convergence in the enlarged European Union(EU). Our general measure of fiscal convergence is based on satisfying Maastricht fiscal criteria that require prudent fiscal behavior

\footnotetext{
* Corresponding author.

E-mail address: tyigit@bilkent.edu.tr (T.M. Yigit).
} 
by the new members before their entry to the EMU. We examine the performance of the ten EU newcomers, as well as that of the Eurozone by using alternative measures of fiscal convergence by employing tests that allow for structural breaks. Our results suggest questionable fiscal convergence in the EU in general and large heterogeneity in convergence in particular.

Our study is motivated by the increasing attention fiscal performance in the EU has been receiving since the formulation of the convergence criteria under the Maastricht treaty in $1992 .{ }^{1}$ Over that time, the two fiscal criteria limiting the deficit and debt ratios within a percentage of GDP have come under sharp scrutiny. ${ }^{2}$ These conditions were set to allow qualifying countries to form the Economic and Monetary Union (EMU) in 1999. After this formation, empirical literature has turned to analyzing the new EU fiscal framework under the Stability and Growth Pact and its reform. ${ }^{3}$

Our study explicitly compares fiscal convergence trends during Accession, Membership and the Stability Growth Pact periods. It also considers ten new members that joined the EU in May 2004, ${ }^{4}$ as well as groups of the EU core and periphery countries. Since all newcomers must eventually join the Eurozone once they satisfy the Maastricht criteria, several observers have raised concerns about the poor fiscal performance of some new members. ${ }^{5}$ Many of the new EU members have, therefore, been placed under the Excessive Deficit Program (EDP) since their entry in 2004. In this respect, our empirical study offers an alternative way to evaluate the necessity for the EDP. ${ }^{6}$

Theoretical literature on fiscal convergence is scant. Based on a simple theoretical framework where agents agree on the long-term goals, Onorante (2004) shows that fiscal constraints lead to implicit coordination characterized by lower deficits, low interest rates and controlled inflation. The model provides an argument for benefits of fiscal convergence for acceding country and the stability of the existing monetary union. In this respect, existing empirical literature on fiscal policy coordination in the EU countries provides support to theoretical benefits of fiscal convergence in large (e.g., Afonso \& Rault, 2007; Arestis, Khan, \& Luintel, 2002; Faini, 2006; Knot \& de Haan, 1995; Sanz \& Velázquez, 2003).

There is also ample evidence that fiscal convergence is systematically associated with enhanced business cycle synchronization, eliminating idiosyncratic fiscal shocks along with evidence that reduced primary fiscal deficits (or higher surpluses) increase the coherence of business cycles across countries (Artis, Fidrmuc, \& Scharler, 2008; Darvas, Rose, \& Szapáry, 2005). It is argued that the increased business cycle coherence along with fiscal convergence makes countries within the region better candidates for a currency union (Darvas et al., 2005). ${ }^{7}$

Given limited studies on fiscal convergence, in particular, for the new EU states, and its importance for EU policymakers, we contribute to the literature by providing a comprehensive empirical study on fiscal convergence of the new EU members to not only the Maastricht benchmark but against that of EU15. We relate the fiscal convergence to the progress in managing public finances and specific risks that the new members' policymakers must overcome in the process of joining the Eurozone. To measure fiscal convergence (to different benchmarks), we employ beta- and sigma-convergence tests, allowing for structural breaks. Towards this end, we use a test developed by Vogelsang (1998), which

\footnotetext{
1 See, for example, Glick and Hutchison (1993), Hutchison and Kletzer (1995), and Watson (1997).

2 See, for example, Corsetti and Roubini (1995), and Holzmann, Herve, and Demmel (1996).

3 Buti and Giudice (2002), Orban and Szapary (2004), Tanzi (2004), Eichengreen (2005), Eijffinger (2005), Feldstein (2005), and Schuknecht (2005).

${ }^{4}$ Eight of them were Central and Eastern European countries (hereafter the CEE8), namely the Czech Republic, Estonia, Hungary, Latvia, Lithuania, Poland, the Slovak Republic, and Slovenia. The other new members were Cyprus and Malta. Slovenia joined the Eurozone in 2007. Slovak Republic was approved to join it in 2009.

5 Berger et al. (2004) point out that deteriorating fiscal performance, especially in Central European countries, may constrain these members from satisfying the Maastricht criteria successfully because continuing large fiscal deficits can create inflationary pressures. Further arguments with the same opinion are voiced by de Grauwe and Schnabl (2004).

${ }^{6}$ Since the underlying idea in fiscal rules of the EU is debt sustainability, our paper is related to recent studies on debt sustainability of developed and developing countries (e.g., Uctum et al., 2006; Uctum \& Wickens, 2000), as well as fiscal sustainability in the EU15 in general (e.g., Afonso \& Rault, 2007; Hughes, Lewis, \& Lewis, 2007).

7 Since both the Maastricht convergence criteria and the Stability and Growth Act require prudent fiscal behavior before entry to the EMU, they indirectly move EU closer to an optimum currency area in the sense of Mundell (1961). Fidrmuc and Korhonen $(2003,2006)$ show that at least some new members have already achieved a sufficient degree of business cycle synchronization.
} 
is particularly suitable for analyzing absolute convergence. ${ }^{8}$ In this approach, we are confronted with the existing empirical evidence on structural breaks in many economic indicators during the transition and pre-accession process in the Central and Eastern European (CEE) countries. ${ }^{9}$ Since such structural breaks in economic series may distort the findings, we employ the modified version of the Vogelsang test, which allows for structural breaks (see Section 2 for details). His method not only allows for structural breaks but is also flexible enough to allow researchers to derive convergence estimates reliably, yielding more reliable inference about fiscal convergence than those found in earlier studies.

One way to test for the fiscal convergence of the new members toward the EU is to compare their distance from convergence criteria as set in the Maastricht Treaty: (1) fiscal deficit up to 3\% of GDP and (2) national debt up to 60\% of GDP. In this respect we do not dispute or discuss the choice of the two ratio-values. Instead we complement the previous criteria with an alternative way of measuring the fiscal convergence in the EU newcomers with respect to the two synthetic benchmarks: (1) the EU core represented by Austria, Belgium, France, Germany and the Netherlands; and (2) the EU periphery represented by Greece, Portugal, and Spain. This alternative measure of fiscal convergence is consistent with the Stability and Growth Act, since we test whether any of the new EU members have been performing like the old EU countries (EU15). ${ }^{10}$

In the next section, we introduce the methodology. In Section 3, we describe our data. Empirical results are reported in Section 4. The last section concludes and provides some policy implications.

\section{Methodology}

The analysis of convergence has been an active, as well as challenging, field of interest since the late 1980s. ${ }^{11}$ Numerous methods have been used to analyze different measures of convergence, namely absolute or conditional beta-convergence, sigma-convergence, and stochastic convergence. While the former two types analyzed the issue of catching up, the latter and more recent type focused on the synchronization of shocks and cross-sectional units moving together in time. The enlargement of the EU has refocused interest in the issue of new entrants "catching up" to the core EU members. Crosssectional tests mostly used to analyze $\beta$-convergence were criticized on the grounds of over-rejecting the null hypothesis of no convergence (Bernard \& Durlauf, 1996; Quah, 1996). These criticisms pushed researchers to apply time series (or panel data) methodologies to introduce a second dimension to $\beta$-convergence.

A new test introduced by Vogelsang $(1998,1999)$ deals with the $\beta$-convergence issue by relying on time-series methodology. ${ }^{12}$ Following this literature, we consider a simple model of convergence towards a benchmark as

$$
y_{t}=\mu+\delta t+\gamma x_{t}+u_{t}
$$

where $y_{t}$ is the log difference of a variable from a benchmark. In our case, for example, it is the budget deficit-to-GDP ratio of country $i$ minus the Maastricht (or other) benchmark at time $t$; while $\mu$ is an intercept to capture the initial level of the deviation; $t$ is a deterministic time trend; $x_{t}$ includes control variables if any; and $u_{t}$ is the residual term. In such a set-up, $\beta$-convergence requires that for a country where $\mu$ is initially significantly negative, meaning that the country is lagging behind, the trend coefficient $\delta$ should have the opposite sign (positive) and be statistically significant. Carlino and Mills (1993) developed this test with a very restricted form of serial correlation for the residual term,

\footnotetext{
${ }^{8}$ Until recently, the cross-sectional tests used in analyzing absolute convergence were criticized for over-rejection of the null hypothesis of no convergence (Bernard \& Durlauf, 1996), shifting the emphasis to conditional and stochastic convergence. However, the need to meet the EU criteria for full EMU membership has regenerated interest in absolute convergence.

9 See, for example, Dibooglu and Kutan (2001), Kočenda (2005), and Égert et al. (2006). It should also be recognized that the transition alone represented a massive structural shift by definition.

${ }^{10}$ For evidence on considerable monetary convergence within new EU members, see Kočenda (2001), Kutan and Yigit (2004, 2005). Brada, Kutan, and Zhou (2005) and Kutan and Yigit (2007) provide evidence on real convergence within new EU members and recent EU members, respectively.

11 For recent discussions, see Taylor (1999) and de la Fuente (2002).

12 See Tomljanovich and Vogelsang (2002) for its application on US data.
} 
namely AR(2). Vogelsang (1998) extended the analysis of this specification to $u_{t}$ with an unknown form of serial correlation, allowing for specifications ranging from integration of order zero, $I(0)$, to order one, $I(1)$. Since the possibility of no convergence implies non-stationarity of the error terms, one can draw a false inference on the trend coefficient when the errors are assumed to be stationary AR(2). ${ }^{13}$ Vogelsang's (1998) methodology, in the spirit of equation (1), considers the following Partial Sums with $J$ correction (PSW) test statistic that helps to alleviate the above problems. ${ }^{14}$ It is defined as

$$
P S W_{T}=\frac{T^{-1}(R \hat{\beta}-r),\left[R\left(X^{\prime} X\right)^{-1} R^{\prime}\right]^{-1}(R \hat{\beta}-r)}{\left(100 T^{-1} s_{Z}^{2} \exp \left(b J_{T}(m)\right)\right)}
$$

where $X$ and $\beta$ consist of [ $1 t$ ] and [ $\mu \delta$ ] respectively, $s_{z}^{2}$ is the standard deviation of the partial cumulated sum of $y_{t}$, and $J_{T}$ is the Park and Choi (1988) unit root test statistic obtained from the following regression:

$$
\begin{aligned}
& y_{t}=X_{t} \beta+\sum_{\substack{i=2 \\
\left(R S S_{y}-R S S_{J}\right)}}^{m} c_{i} t^{i}+u_{t} \\
& J_{T}(m)=\frac{S_{J}}{}
\end{aligned}
$$

In other words, $J_{T}$ is the Wald statistic that tests the joint hypothesis of $c_{2}=\cdots=c_{m}=0$. In Monte Carlo simulations, Vogelsang (1998) finds the values of $b$ and $m$, for which the above tests would be comparable and valid for every type of serial correlation form, including unit roots.

Despite the great flexibility of these tests in deriving the mean and trend coefficient estimates in time series with varying stationarity properties, we need to be careful when using this methodology in the analysis of post-transition economies. The reason stems from the volatile nature of these economies and the presence of structural shifts that are documented in the empirical literature (e.g., Dibooglu \& Kutan, 2001; Égert, Jiménez-Rodríguez, Kočenda, \& Morales-Zumaquero, 2006; Kočenda, 2005).

We obtain robust results by using Vogelsang's (1999) methodology, which allows for structural breaks in the modification of the statistics by including the possibility of shifts in the trend function. The test has been designed in two versions: one with predetermined breaks and the other with endogenous break selection. We favour the latter one. First, we estimate the break date using the optimal tests of Andrews and Ploberger (1994). Then, using the estimated break date, normalized critical values are obtained using the following altered version of equation (1):

$$
y_{t}=\mu_{1} D U_{1 t}+\mu_{2} D U_{2 t}+\delta_{1} D T_{1 t}+\delta_{2} D T_{2 t}+\gamma x_{t}+u_{t}
$$

where $D U_{1 t}=1$ if $t \leq T_{b}$ (the break date) and zero otherwise, $D U_{2 t}=1$ if $t>T_{b}$ and zero otherwise, $D T_{1 t}=t$ if $t \leq T_{b}$ and zero otherwise, and finally $D T_{2 t}=t-T_{b}$ if $t>T_{b}$ and zero otherwise.

To derive inferences on fiscal convergence, we test the significance and the opposite signs in the pair of coefficients, $\mu_{1}, \delta_{1}$ and $\mu_{2}, \delta_{2}$. The null hypothesis is that trend coefficients are equal to zero, which in our framework translates to no trend in developments of budget deficit or debt. An alternative hypothesis of trend coefficients being statistically different from zero indicates existence of positive or negative trends in developments of both measures, depending on the sign. In particular, the finding of (statistically significant) mean and trend coefficients with opposite signs indicates how countries with different starting positions approach the benchmark. For example, consider the dependent variable being the budget deficit (surplus) to GDP ratio in country $i$ minus the $3 \%$ deficit benchmark. In that case, a positive intercept indicates a surplus or a deficit ratio below $3 \%$, since the negative $3 \%$ benchmark subtracted from a less negative deficit ratio yields positive value. Accordingly, a positive trend coefficient indicates improving comparative fiscal stance. The reverse follows for the opposite

\footnotetext{
${ }^{13}$ When $u_{t}$ is $I(1)$, the estimate of $\beta$ obtained from the above regression is not related to the true trend, and information on $\beta$ must be obtained from the estimate of the intercept in the autoregressive representation of $y_{t}$.

14 See Vogelsang (1998) for further test statistics and a deeper elaboration of the tests.
} 
combination of signs. We supplement these results by tests of $\sigma$-convergence, ${ }^{15}$ since confirmation of absolute convergence requires both $\beta$ - and $\sigma$-convergence.

Granted that the Vogelsang (1999) methodology allows for only a single break, and it is desirable to use methodologies that allow for more breaks, like Bai and Perron (BP henceforth, 1998), data availability and the performance of BP under $I(1)$ errors prevent us from pursuing these alternative methodologies. Uctum, Thurston, and Uctum (2006) analyze the mean reversion of the debt of developed and developing countries to examine sustainability by using a combination of the BP and Zivot and Andrews (1992) tests. These tests revolve around the same idea by testing for the mean reverting trends and temporary fluctuations around them in the existence of breaks-hence, broken trend stationarity. We prefer the Vogelsang methodology, since it gives more accurate inference on the trend functions, and breaks in them, regardless of the (non)stationarity of the data series. ${ }^{16}$ This way, we do not have to test for the stationarity of the series around the trend values to evaluate convergence to benchmarks (or debt sustainability, in the case of Uctum et al., 2006).

\section{Data and sample period}

We assess fiscal convergence of the CEE8, Cyprus, and Malta using the official Maastricht criteria of the deficit-to-GDP and debt-to-GDP ratios. ${ }^{17}$ We further examine fiscal convergence of these countries with respect to two naturally produced benchmarks. These are deficit and debt ratios achieved in the core of the EU, represented by the average values in Austria, Belgium, France, Germany, and the Netherlands, and the EU periphery, represented by average values from Greece, Portugal, and Spain. An analysis of the deficit and debt ratios is also consistent with testing the theoretical implications of the disciplining effects of monetary unions. We include GDP growth rate as a control variable in the deficit regressions in order to incorporate cyclical effects on deficit.

We use quarterly data from 1995:1 through 2005:4 for variables under research. The time span was chosen because: (1) official EU membership applications started in 1995, and (2) EuroStat began using the harmonized time series on macroeconomic variables at that time, and (3) consistent data are available for all countries through the end of 2005. In addition, the post-1995 period excludes the major transition-related shocks observed in the early 1990s. The data are obtained primarily from the EuroStat database and checked for consistency against the International Financial Statistics of the IMF. In case of missing or incomplete observations, data are gathered from the individual central banks and finance ministries. ${ }^{18}$ We also annualize the quarterly debt and deficit data by summing the four quarters and then using this sum to obtain the deficit-to-GDP and debt-to-GDP ratios. We should reiterate, at this point, that the serial correlation generated by the methodology used for deseasonalizing the data is of little concern here since the Vogelsang test is able to handle broad forms of serial correlation.

\section{Empirical findings}

The Vogelsang test results are displayed in Tables 1 and 2. They display the results for PSW (Partial Sums with $J$ correction) tests, given by the specification in equation (2). The initial column in each table lists country variables. The next pair of columns for $\mu_{1}$ and $\delta_{1}$ corresponds to pre-break mean and growth rates, respectively. Similarly, the two columns headed by $\mu_{2}$ and $\delta_{2}$ list post-break mean and growth rates. The last column contains the estimated break date using the maximum $T^{-1} W_{T}$ statistic

\footnotetext{
${ }^{15}$ Sigma-convergence occurs when the cross-sectional standard deviation of a variable for a group of economies decrease in time.

${ }^{16}$ The determination of the structural break date in Uctum et al. (2006) and our paper is quite similar.

17 In terms of country coverage of the new EU member states, our paper is related to Hughes et al. (2007), but their focus is on fiscal sustainability, rather than fiscal convergence. They study debt dynamics for the eight new members from Central and Eastern Europe that are part of our sample as well.

${ }^{18}$ In some cases, quadratic interpolation of annual data was necessary to fill some missing data points because the empirical methodology we use relies on uninterrupted data. Quadratic interpolation of annual data was used for debt in the case of Austria, Estonia, France, Germany, and the Netherlands, and for the Portuguese deficit and second half of the Greek deficit.
} 
Table 1

Budget deficit convergence to Maastricht benchmark, core, and periphery

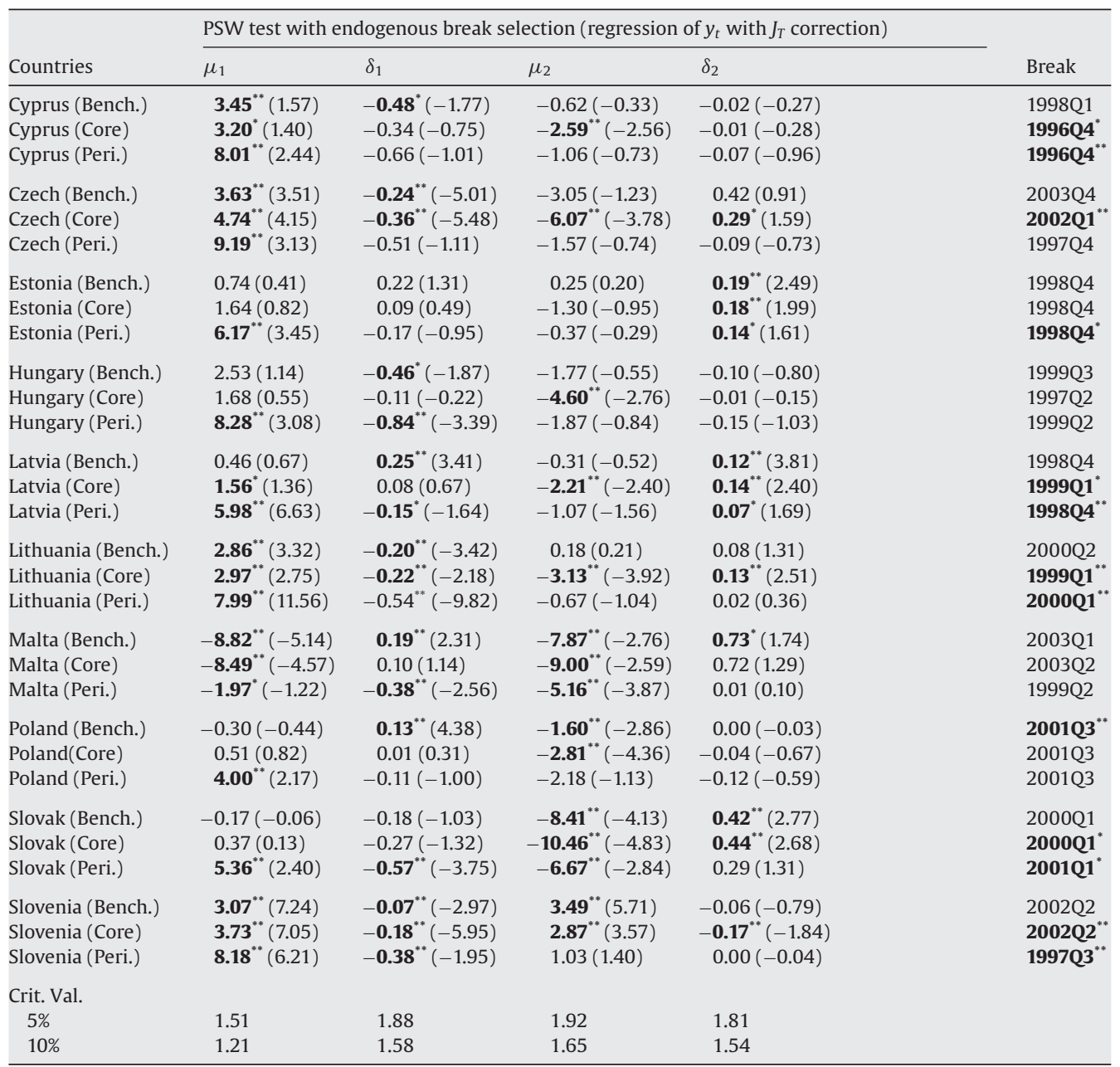

Note: the first dependent variable is the budget deficit (surplus) to GDP ratio in country $i$ minus the $3 \%$ deficit benchmark (a positive number indicates a surplus or a deficit ratio below $3 \%$ since the negative $3 \%$ benchmark subtracted from a less negative deficit ratio yields positive values). For the core (periphery), it is the deficit to GDP ratio in country $i$ minus the core (periphery) deficit ratio (hence a negative number indicates a deficit ratio worse than that of the core (periphery) and a positive trend indicates lowering comparative deficit ratios). Therefore, a positive trend coefficient indicates improving comparative fiscal stance. GDP growth (differences, when necessary) has been used to control for cyclicality. The numbers in the parentheses for the above table and those that follow below indicate the test statistic associated with the coefficient estimate and are to be compared with the critical values at the bottom of the table. The term ****) indicates $95 \%(90 \%)$ significance. Significance levels of breaks are determined using the critical values in Andrews and Ploberger (1994). All significant coefficient values are displayed in bold.

of Andrews and Ploberger (1994). Following the theoretical grounds of the methodology employed, we apply a $10 \%$ trimming from each end of the sample since the break dates close to the endpoints are unreliable and should mostly be disregarded. ${ }^{19}$ We display the test statistics below the coefficient

\footnotetext{
19 Due to our small sample size, we run auxiliary Monte Carlo simulations to check the validity of the Vogelsang (1999) methodology. We run 5000 simulations with generated series with structural breaks (both in the mean and trend) to find that the methodology performs well in getting the true point estimates only with wider standard errors in comparison to the
} 
Table 2

Consolidated debt/GDP convergence to Maastricht benchmark, core, and periphery

\begin{tabular}{|c|c|c|c|c|c|}
\hline \multirow[b]{2}{*}{ Countries } & \multicolumn{4}{|c|}{ PSW test with endogenous break selection (regression of $y_{t}$ with $J_{T}$ correction) } & \multirow[b]{2}{*}{ Break } \\
\hline & $\mu_{1}$ & $\delta_{1}$ & $\mu_{2}$ & $\delta_{2}$ & \\
\hline Cyprus (Bench.) & $8.81^{* *}(3.99)$ & $-0.46^{* *}(-2.04)$ & $6.51^{* *}(3.99)$ & $-0.75^{* *}(-7.61)$ & 1998Q4 \\
\hline Cyprus (Core) & $4.05^{* *}(1.77)$ & $-0.64^{* *}(-2.70)$ & $-2.57(-1.52)$ & $-\mathbf{0 . 7 0 * *}(-6.82)$ & 1998Q4 \\
\hline Cyprus (Peri.) & $\mathbf{3 2 . 6 1}^{* *}(17.72)$ & $-0.83^{* *}(-8.83)$ & $-0.26(-0.08)$ & $0.09(0.18)$ & $2003 Q 1$ \\
\hline Czech (Bench.) & $\mathbf{5 1 . 5 0}^{* *}(12.45)$ & $-0.26(-1.33)$ & $\mathbf{2 5 . 1 9}^{* *}(2.66)$ & $0.27(0.14)$ & $2003 Q 4^{* *}$ \\
\hline Czech (Core) & 46.11** $^{* *}(12.45)$ & $-0.38^{* *}(-2.17)$ & $\mathbf{1 8 . 0 8}^{* *}(2.13)$ & $0.23(0.13)$ & $2003 Q 4^{* *}$ \\
\hline Czech (Peri.) & $\mathbf{6 7 . 5 9}^{* *}(10.66)$ & $0.69(0.55)$ & $\mathbf{7 3 . 5 5}^{* *}(26.56)$ & $-\mathbf{1 . 0 0}^{* *}(-7.66)$ & 1996Q4 \\
\hline Estonia (Bench.) & $\mathbf{5 0 . 3 2}^{* *}(92.52)$ & $\mathbf{0 . 1 9}^{* *}(5.76)$ & $\mathbf{5 3 . 8 9 * *}^{* *}(73.38)$ & $0.06(0.83)$ & $2001 Q 4^{* *}$ \\
\hline Estonia (Core) & $\mathbf{4 5 . 6 9 * *}^{* *}(58.02)$ & $0.00(0.08)$ & $\mathbf{4 4 . 5 0}^{* *}(44.10)$ & $\mathbf{0 . 2 1}^{* *}(2.17)$ & 2001Q3 \\
\hline Estonia (Peri.) & $74.86^{* *}(42.90)$ & $-0.33^{* *}(-4.03)$ & $67.43^{* *}(16.88)$ & $-0.06(-0.08)$ & 2003Q4 \\
\hline Hungary (Bench.) & $-18.65^{* *}(-3.87)$ & $1.05^{* *}(3.11)$ & $8.53(1.60)$ & $-0.44(-1.00)$ & $2000 Q 4^{*}$ \\
\hline Hungary (Core) & $-27.21^{* *}(-4.65)$ & $1.38^{*}(1.60)$ & $-\mathbf{6 . 2 0}^{* *}(-1.92)$ & $0.05(0.28)$ & $199703^{*}$ \\
\hline Hungary (Peri.) & $-0.21(-0.04)$ & $1.51^{* *}(2.46)$ & $\mathbf{1 6 . 5 0}^{* *}(5.41)$ & $-0.09(-0.56)$ & 1998Q1* \\
\hline Latvia (Bench.) & $\mathbf{4 9 . 1 2}^{* *}(50.80)$ & $0.00(0.03)$ & $45.83^{* *}(60.75)$ & $0.02(0.45)$ & 1999Q1 \\
\hline Latvia (Core) & $\mathbf{4 4 . 8 4}^{* *}(50.76)$ & $-0.24^{* *}(-3.30)$ & $35.41^{* *}(44.20)$ & $\mathbf{0 . 1 8}^{* *}(3.14)$ & $1999 Q 4^{* *}$ \\
\hline Latvia (Peri.) & $73.88^{* *}(28.88)$ & $-\mathbf{0 . 6 0}^{* *}(-4.94)$ & $\mathbf{5 8 . 0 9}^{* *}(9.92)$ & $0.22(0.19)$ & $2003 Q 4^{*}$ \\
\hline Lithuania (Bench.) & $\mathbf{3 6 . 6 8}^{* *}(23.38)$ & $0.01(0.05)$ & $26.966^{* *}(19.90)$ & $\mathbf{0 . 5 8}^{* *}(6.34)$ & $1999 Q 3^{* *}$ \\
\hline Lithuania (Core) & $31.74^{* *}(17.77)$ & $-0.14(-0.89)$ & $\mathbf{1 7 . 1 0}^{* *}(11.09)$ & $\mathbf{0 . 6 9}^{* *}(6.62)$ & $1999 Q 3^{* *}$ \\
\hline Lithuania (Peri.) & $\mathbf{6 2 . 1 2}^{* *}(17.18)$ & $-0.63^{* *}(-2.09)$ & $\mathbf{3 8 . 2 9 * *}^{* *}(11.67)$ & $\mathbf{0 . 6 2}^{* *}(2.70)$ & $1999 Q 4^{* *}$ \\
\hline Malta (Bench.) & $24.97^{* *}(11.23)$ & $-\mathbf{1 . 1 9 * *}^{*}(-7.65)$ & $1.92(0.79)$ & $-\mathbf{1 . 0 5}^{* *}(-5.12)$ & 2000Q4 \\
\hline Malta (Core) & $\mathbf{2 0 . 3 1 * *}(9.98)$ & $-1.37^{* *}(-9.63)$ & $-\mathbf{8 . 2 0} \mathbf{0}^{* *}(-3.65)$ & $-\mathbf{0 . 8 7}^{* *}(-4.67)$ & 2000Q4 \\
\hline Malta (Peri.) & $\mathbf{4 9 . 1 2}^{* *}(11.76)$ & $-1.60^{* *}(-3.48)$ & $19.16{ }^{* *}(6.54)$ & $-\mathbf{0 . 8 8}^{* *}(-5.18)$ & 1998Q3 \\
\hline Poland (Bench.) & $8.93^{* *}(3.43)$ & $\mathbf{0 . 8 1 * *}(3.00)$ & $20.82^{* *}(10.81)$ & $-0.23^{* *}(-1.95)$ & $1998 Q 4^{* *}$ \\
\hline Poland(Core) & $4.36^{* *}(3.35)$ & $\mathbf{0 . 6 0}^{* *}(4.74)$ & $\mathbf{1 1 . 2 9}^{* *}(11.11)$ & $-0.16 *(-2.48)$ & $199901^{*}$ \\
\hline Poland (Peri.) & $\mathbf{3 3 . 2 8}^{* *}(11.91)$ & $0.33(1.16)$ & $\mathbf{3 3 . 5 1}^{* *}(16.20)$ & $-\mathbf{0 . 2 9 * *}(-2.32)$ & 1998Q4 \\
\hline Slovenia (Bench.) & $\mathbf{4 0 . 3 8}^{* *}(17.98)$ & $-0.16(-1.02)$ & $23.95^{* *}(9.67)$ & $-0.15(-0.74)$ & 2000Q4 \\
\hline Slovenia (Core) & $\mathbf{3 5 . 7 2}^{* *}(15.84)$ & $-\mathbf{0 . 3 4}^{* *}(-2.16)$ & $13.83^{* *}(5.56)$ & $0.02(0.10)$ & 2000Q4 \\
\hline Slovenia (Peri.) & $\mathbf{6 5 . 2 8}^{* *}(22.05)$ & $-0.72 * *(-3.48)$ & $\mathbf{3 4 . 5 7 ^ { * * } ( 1 0 . 5 9 )}$ & $-0.09(-0.33)$ & $2000 Q 4^{*}$ \\
\hline Slovak (Bench.) & $\mathbf{4 8 . 6 8}^{* *}(54.04)$ & $-0.77^{* *}(-9.74)$ & $\mathbf{3 6 . 0 3}^{* *}(46.32)$ & $-0.22^{* *}(-4.26)$ & $1999 Q 3^{* *}$ \\
\hline Slovak (Core) & $43.92^{* *}(33.29)$ & $-0.94^{* *}(-7.73)$ & $26.52{ }^{* *}(24.48)$ & $-\mathbf{0 . 1 3}^{*}(-1.80)$ & $1999 Q 2^{* *}$ \\
\hline Slovak (Peri.) & $73.25^{* *}(40.31)$ & $-1.28^{* *}(-8.45)$ & $47.10^{* *}(28.58)$ & $-0.21^{* *}(-1.86)$ & $1999 Q 4^{* *}$ \\
\hline \multicolumn{6}{|l|}{ Crit. Val. } \\
\hline $5 \%$ & 1.51 & 1.88 & 1.92 & 1.81 & \\
\hline $10 \%$ & 1.21 & 1.58 & 1.65 & 1.54 & \\
\hline
\end{tabular}

Note: values are expressed as percentages. The dependent variable for the benchmark is the consolidated debt to GDP ratio in country $i$ minus the $60 \%$ benchmark (a positive number indicates a debt ratio below $60 \%$ since the negative $60 \%$ benchmark subtracted form a less negative debt ratio yields positive values). For the core (periphery), it is the consolidated debt to GDP ratio in country $i$ minus the core (periphery) debt ratio (hence a negative number indicates a debt ratio worse than that of the core (periphery) and a positive trend indicates lowering comparative debt ratios). Therefore, a positive trend coefficient indicates improving comparative debt position. The $\operatorname{term}^{* *}\left(^{*}\right)$ indicates $95 \%(90 \%)$ significance. Significance levels of breaks are determined using the critical values in Andrews and Ploberger (1994). All significant coefficient values are displayed in bold.

estimates and the asymptotic critical values for the endogenous break option of the PSW tests at the bottom rows of each table, respectively.

When interpreting results, readers should note that positive trend coefficients represent improvements of fiscal position in comparison to the Union, suggesting that new EU members improve their fiscal position with respect to the old Union members. For instance, a positive trend coefficient shows new members' fiscal position is improving further, away from the $3 \%$ deficit benchmark. In short, a

Vogelsang study. These simulations also show that the test performs well under $10 \%$ trimming even in small samples. Simulation results are available upon request. 
positive trend coefficient is always good. We supplement this brief explanation at the bottom of each table by indicating the dependent variable and providing a brief guideline to interpret the results easily.

The dependent variables in the analyses are the ratio of the budget deficit (surplus) to GDP and total debt to GDP in a new member country minus the benchmarks, $3 \%$ for deficit and $60 \%$ for total debt. Since all deficits (debt) are indicated by a negative number (e.g., minus $2 \%$ stands for two percent deficit), all positive mean values indicate surplus or deficit (debt) ratios below (less negative) $3 \%$ (60\%), zero values indicate deficit (debt) of exactly 3\% (60\%), and negative values indicate deficit (debt) ratios greater than $3 \%$ (60\%). GDP growth is used as a control variable accounting for cyclical deficit movements, therefore, we modify the test specification according to the choice of benchmark. Although we use the country specific growth levels in the $3 \%$ benchmark regressions, for instance, we prefer growth deviations for the core and periphery regressions. Accordingly, negative trend coefficients depict deficit (debt) increases (or declining budget surpluses) with respect to the benchmark, suggesting fiscal divergence relative to the benchmark, and positive coefficients suggest exactly the opposite (fiscal convergence).

As a complementary measure of fiscal convergence, we also report the $\sigma$-convergence tests to be able to test whether the fiscal position of the new EU members are diverging or converging towards the core and periphery EU members. We illustrate the $\sigma$-convergence levels graphically. Note that since the sigma (standard deviation in our case) is calculated cross-sectionally, the choice of benchmark does not alter the results.

\subsection{Fiscal convergence: budget deficit results}

Table 1 examines whether the mean and trend coefficients of equation (4) are (i) statistically different from zero, implying that there is a positive or negative trend in budget deficits, and (ii) have opposite signs, indicating that countries with higher (or more negative) deficit approach the benchmark or each other. Initially, we notice that the pre-accession period (before 2000) is represented by significant levels of lack of fiscal convergence. The pattern that emerges from the table, in general, is that the earlier lack of fiscal convergence subsides as membership gets closer and that the countries with higher level of non-convergence tend to perform with more discipline than the ones with low deficits (better convergence).

The deficit-to-GDP ratio with respect to the benchmark of the core shows, in essence, a confirmation of the $3 \%$ benchmark (Table 1 ) results. All new members worsen their deficit position in comparison to the core countries, which can be noted from the significantly lower post-break means. Initially, better fiscal positions of these countries in comparison to the core imply that their attention was focused elsewhere. In other words, the new members have higher unjustified expansion in their deficits than the core countries. The Czech Republic, Baltic countries, and Slovakia try to improve on their poor prebreak performance by having positive trends in the second half of the sample period. The observed fiscal non-convergence conclusion is strengthened even more when we compare the new members with the periphery. The drastic difference in fiscal position between the new members and the periphery at the beginning of the sample period had not only been closed in all countries, but it reverses direction in many countries. This indicates that of all three groups, the periphery has controlled its unjustified deficits best. Latvia and Estonia are the only new EU countries to have a higher trend in their budget performance in the second half of the sample period. In short, the difference between the new members and the core and periphery regressions point towards more fiscal convergence in the EU15 than in the ten new members.

Inspecting Fig. 1a for sigma convergence, we notice that the older EU members are quite in conjunction with each other, while the new ten members show a very slow decline in their cross-sectional standard deviation. Accounting for the average mean deficit of each group (Fig. 1b) confirms this finding with the deficit condition of the new members exhibiting an inferior trend, when compared to the older members. The periphery countries show constant decline in the mean and standard deviation of the deficit ratio, while the core countries seem to lose focus after 2001. Mean ratio of the newcomers shows no improvement (or decline) with a flat trend during the period under research. The old members seem to be converging to a higher than desired equilibrium. From this perspective, convergence of the newcomers in terms of deficit-to-GDP ratio towards either the core or the periphery looks like a dubious enterprise, confirming the necessity of EDP. 

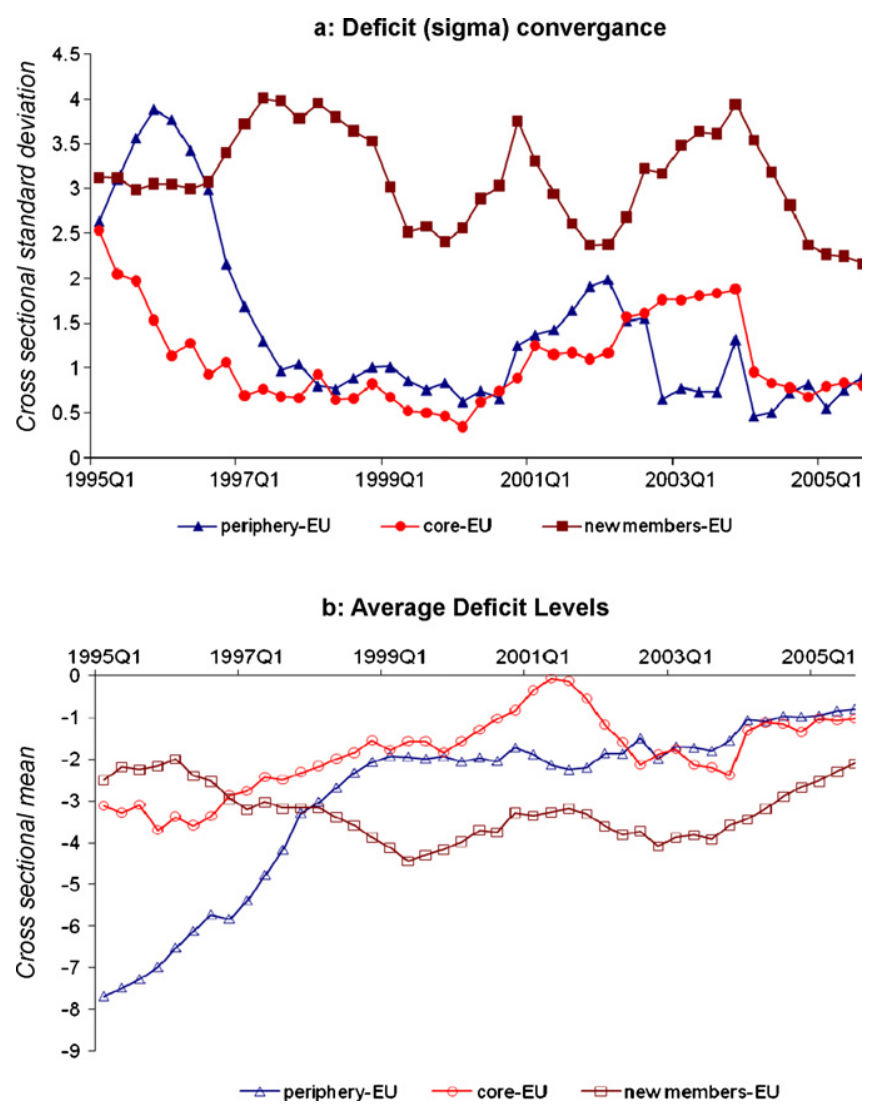

Fig. 1. (a) Deficit (sigma) convergence. (b) Average deficit levels.

\subsection{Fiscal convergence: debt results}

Convergence of the general government debt-to-GDP ratio toward the Maastricht benchmark of $60 \%$, as well as toward the core and periphery, is displayed in Table 2 and Fig. 2, similar to the budget deficit. The key dependent variable in Table 2 is the consolidated debt-to-GDP ratio in a new member country minus the $60 \%$ benchmark. A positive number indicates a debt ratio below $60 \%$, since the negative $60 \%$ benchmark subtracted from a less negative debt ratio yields positive values. Therefore, for example, a mean value of 40 means a 20\% debt-to-GDP ratio. All countries, except Hungary, start with a debt-to-GDP ratio lower than the Maastricht benchmark of $60 \%$, since the mean coefficients are all positive. The few positive trend coefficients observed in the pre-break period either reverse direction or lose significance in the post-break period, suggesting that the new member countries are increasing their debt-to-GDP ratio or showing lack of fiscal non-convergence. Countries like Malta and the Czech Republic stand out with a large deterioration of their indebtedness toward the benchmark.

A similar tendency and a clearer picture are observed when the $60 \%$ benchmark is replaced by the actual debt-to-GDP ratio in the core and the periphery. Again, the big debt position difference at the beginning of the sample period narrows down the second half due to the fiscal indiscipline of the new members. Only Hungary stands out as the consistently prudent country among the new members. Estonia and Poland seem to show fiscal convergence in post- and pre-2000, respectively, not displaying as consistent a picture as Hungary. A quick glance at Fig. 2 shows a slight decline in the core's debt situation, while the high debt of the periphery keeps the new members within comparatively 


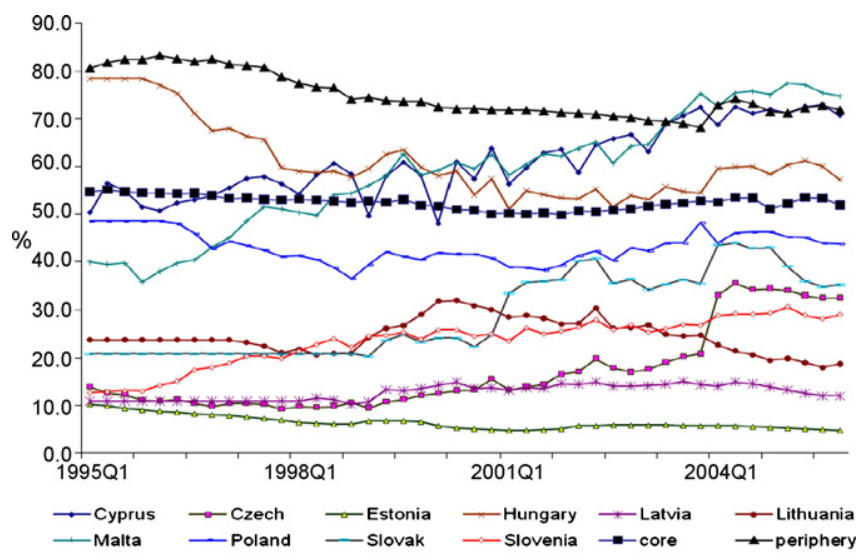

Fig. 2. Debt to GDP ratio.

acceptable debt positions. However, we can hardly call it a success story because their indebtedness increases in general and its dynamics are discomforting.

Both results from Table 2 and the sigma convergence results in Fig. 3a support earlier findings, as we observe that the new ten members have outperformed the EU15 members, especially before 2001. Afterwards, their fiscal convergence loses some of its momentum, as the variation of the debt
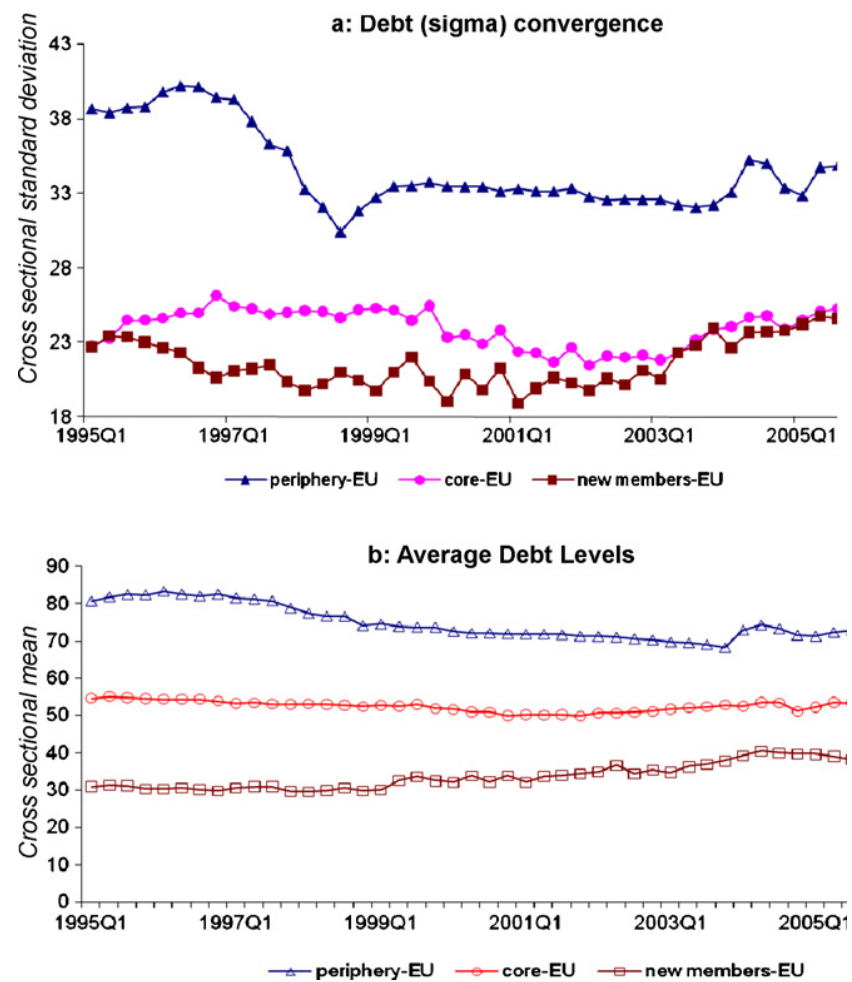

Fig. 3. Debt (sigma) convergence. (b) Average debt levels. 
positions of the new ten members evolve at par with the core after 2003. Fiscal convergence of the periphery starts to improve after 1996 but loses its original dynamics in 1998, worsening further in the recent period. The average debt ratios in Fig. 3b confirm this finding, since the periphery as well as the core show worse debt positions than the newcomers. On the other hand, its dynamics point at slowly diminishing debt position over the time. The results of the sigma convergence thus support better performance of the new members as compared to the older ones, but this finding is confronted with the worsening dynamics of their debt position.

\section{Conclusions and policy implications}

Our study examines the fiscal convergence of the new EU members with respect to EU15. Employing alternative measures of fiscal convergence and vastly flexible tests of convergence that allow for structural breaks, our study provides enhanced inference on fiscal convergence. An important finding that emerges from our study is that a significant level of heterogeneity exists in fiscal convergence, raising concerns about the ability of monetary unions to provide fiscal convergence for its members. Given limited sample size, our results should be interpreted cautiously.

An important implication of our results is that the ongoing reform of the public finance systems in the whole EU27 is an agenda that is timely and should not to be underestimated. For the new EU members, this issue becomes even more important, because a neglect of public finance reforms and lack of fiscal convergence could lead to endangering completion of the Maastricht criteria and the consideration of entry into the Eurozone.

Our findings suggest the need to design further policies to improve fiscal performance. For example, EU policymakers may consider adopting fiscal policy rules, rather than a counter-cyclical fiscal policy. Some countries, such as Poland and the Netherlands, have already introduced fiscal rules into the laws and constitutions (Tanzi, 2005). Of course, the fact that the member states have different fiscal positions certainly creates implementation problems, at least initially. Tanzi suggests that "flexibility is required as to the time needed to conform to the rule, but the rule should not be relaxed to the point of making sinning more acceptable for everyone" (p. 63).

\section{Acknowledgements}

We thank Jan Babecky, John Bonin, Josef Brada, Balázs Égert, Jarko Fidrmuc, Jan Frait, Jan Hanousek, Tomáš Holub, Iikka Korhonen, Kirsten Lommatzsch, Srobona Mitra, Antonin Rusek, Selin Sayek, and anonymous referee for useful comments and suggestions. Any remaining errors are the responsibility of the authors. We also thank to Pierre Siklos (the Editor) and Ken Kasa (the Co-editor) for expediting the review process. GAČR grant (402/08/1376) support is gratefully acknowledged.

\section{References}

Afonso, A., \& Rault, C. (2007). What do we really know about fiscal sustainability in the EU? A Panel Data Diagnostic (Working Paper Number 893). William Davidson Institute.

Andrews, D. W. K., \& Ploberger, W. (1994). Optimal tests when a nuisance parameter is present only under the alternative. Econometrica, 62(6), 1383-1414.

Arestis, P., Khan, M., \& Luintel, K. B. (2002). Fiscal deficits in monetary unions: A comparison of EMU and United States. Eastern Economic Journal, 28(1), 89-103.

Artis, M., Fidrmuc, J., \& Scharler, J. (2008). The transmission of business cycles: Implications for EMU enlargement. Economics of Transition, 16(3), 559-582.

Bai, J., \& Perron, P. (1998). Estimating and testing linear models with multiple structural changes. Econometrica, 66, 47-78.

Berger, H., Kopits, G., \& Szekély, I. (2004). Fiscal indulgence in Central Europe: Loss of the external anchor? (IMF Working Paper WP 04/62).

Bernard, A. B., \& Durlauf, S. N. (1996). Interpreting tests of the convergence hypothesis. Journal of Econometrics, 71, 161-173.

Brada, J. C., Kutan, A. M., \& Zhou, S. (2005). Real and monetary convergence between the European Union's core and recent member countries: A rolling cointegration approach. Journal of Banking and Finance, 249-270.

Buti, M., \& Giudice, G. (2002). Maastricht's fiscal rules at ten: An assessment. Journal of Common Market Studies, 40(5), 823-848.

Carlino, G. A., \& Mills, L. O. (1993). Are U.S. regional incomes converging? Journal of Monetary Economics, 32, 335-346.

Corsetti, G., \& Roubini, N. (1995). Political biases in fiscal policy: Reconsidering the case for the Maastricht Fiscal Criteria. In Eichengreen, Frieden, \& von Hagen (Eds.), Monetary and fiscal policy in an integrated Europe. European and Transatlantic Studies (pp. 118-137). London: Springer. 
Darvas, Z., Rose, A. K., \& Szapáry, G. (2005). Fiscal divergence and business cycles synchronization: Irresponsibility is idiosyncratic (NBER Working Paper No. 11580).

de Grauwe, P., \& Schnabl, G. (2004). Nominal versus real convergence with respect to EMU accession. How to cope with the BalassaSamuelson Dilemma (Discussion Paper RSCAS No. 2004/20). European University Institute.

de la Fuente, A. (2002). On the sources of Convergence: A close look at the Spanish regions. European Economic Review, 46, 569-599.

Dibooglu, S., \& Kutan, A. M. (2001). Sources of real exchange rate fluctuations in transition economies: The Case of Poland and Hungary. Journal of Comparative Economics, 29, 257-275.

Égert, B., Jiménez-Rodríguez, R., Kočenda, E., \& Morales-Zumaquero, A. (2006). Structural changes in Central and Eastern European economies: Breaking news or breaking the ice? Economic Change and Restructuring, 39(1-2), 85-103.

Eichengreen, B. (2005). Europe, the Euro and the ECB: Monetary success, fiscal failure. Journal of Policy Modeling, 27(4), 427-439.

Eijffinger, S. C. W. (2005). On a reformed stability and growth pact. Intereconomics/Review of European Economic Policy, 40(3), 141-147.

Faini, R. (2006). Fiscal policy and interest rates in Europe. Economic Policy, 21(47), 443-489.

Feldstein, M. (2005). The Euro and the stability pact. Journal of Policy Modeling, 27(4), 421-426.

Fidrmuc, J., \& Korhonen, I. (2003). Similarity of supply and demand shocks between the Euro Area and the CEECs. Economic Systems, 27(3), 313-334.

Fidrmuc, J., \& Korhonen, I. (2006). Meta-analysis of the business cycle correlation between the Euro Area and the CEECs. Journal of Comparative Economics, 34(3), 518-537.

Glick, R., \& Hutchison, M. (1993). Fiscal policy in monetary unions: Implications for Europe. Open Economies Review, 4(1), 39-65.

Hughes, H., Lewis, A., \& Lewis, J. (2007). Debt, deficits, and the accession of the new member States to the Euro. European Journal of Political Economy, 23, 316-337.

Holzmann, R., Herve, Y., \& Demmel, R. (1996). The Maastricht Fiscal Criteria: Required but ineffective? Empirica, 23(1), 25-58.

Hutchison, M. M., \& Kletzer, K. M. (1995). Fiscal convergence criteria, factor mobility, and credibility in transition to Monetary Union in Europe. In Eichengreen, Frieden, \& von Hagen (Eds.), Monetary and fiscal policy in an integrated Europe. European and Transatlantic Studies (pp. 138-165). London: Springer.

Knot, K., \& de Haan, J. (1995). Fiscal policy and interest rates in the European community. European Journal of Political Economy, 11, 171-187.

Kočenda, E. (2001). Macroeconomic convergence in Transition Economies. Journal of Comparative Economics, 29(1), 1-23.

Kočenda, E. (2005). Beware of breaks in exchange rates: Evidence from European transition countries. Economic Systems, 29(3), 307-324.

Kutan, A. M., \& Yigit, T. M. (2004). Nominal and real stochastic convergence of transition economies. Journal of Comparative Economics, 32, 23-36.

Kutan, A. M., \& Yigit, T. M. (2005). Nominal and real stochastic convergence: Are the New EU members ready to join the Euro Zone? Journal of Comparative Economics, 33, 387-400.

Kutan, A. M., \& Yigit, T. M. (2007). European integration: Productivity and real convergence. European Economic Review, 51, 1370-1395.

Mundell, R. (1961). A theory of optimum currency area. American Economic Review, 51, 657-665.

Onorante, L. (2004). Fiscal convergence before entering EMU. In Liebscher, Liebscher, et al. (Eds.), The economic potential of a larger Europe (pp. 245-259). Cheltenham, UK/Northampton, MA: Elgar.

Orban, G., \& Szapary, G. (2004). The stability and growth pact from the perspective of the new member states. Journal of Policy Modeling, 26(7), 839-864.

Park, J. Y., \& Choi, B. (1988). A new approach to testing for a unit root (Working Paper \#88-23). Department of Economics, Cornell University.

Quah, D. T. (1996). Empirics for economic growth and convergence. European Economic Review, 40(6), 1353-1375.

Sanz, I., \& Velázquez, F. J. (2003). Has the European integration approximated the composition of government expenditures? A Comparative Analysis between the EU and Non-EU Countries of the OECD (Research Paper 2003/09). Leverhulme Centre for Research on Globalization and Economic Policy, University of Nottingham.

Schuknecht, L. (2005). Stability and growth pact: Issues and lessons from political economy. International Economics and Economic Policy, 2(1), 65-89.

Tanzi, V. (2004). The stability and growth pact: Its role and future. Cato Journal, 24(1-2), 57-69.

Tanzi, V. (2005). Fiscal policy and fiscal rules in the European Union. CESIfo Forum, 3, 57-64.

Taylor, A. M. (1999). Sources of convergence in the late nineteenth century. European Economic Review, 43, 1621-1645.

Tomljanovich, M., \& Vogelsang, T. J. (2002). Are US regional incomes converging? Using new econometric methods to examine old issues. Empirical Economics, 27, 49-62.

Uctum, M., Thurston, T., \& Uctum, R. (2006). Public debt, the unit root hypothesis and structural breaks: A multi-country analysis. Economica, 73(289), 129-156.

Uctum, M., \& Wickens, M. (2000). Debt and deficit ceilings, and sustainability of fiscal policies: An intertemporal analysis. Oxford Bulletin of Economics and Statistics, 62(2), 197-222.

Vogelsang, T. J. (1998). Trend function hypothesis testing in the presence of serial correlation. Econometrica, 66, 123-148.

Vogelsang, T. J. (1999). Testing for a Shift in Trend When Serial Correlation is of Unknown Form, Tinbergen Institute Discussion Paper \#99-016/4. (last version: Cornell Department of Economics, 2001).

Watson, A. M. S. (1997). Aspects of European monetary integration: The politics of convergence. New York/London: St. Martin's Press/Macmillan Press.

Zivot, E., \& Andrews, D. (1992). Further evidence on the great crash, the oil price shock, and the unit root hypothesis. Journal of Business and Economic Statistics, 10, 251-270. 